\title{
Systematics of the Patagonian Genus Acrostomus Kuschel (Coleoptera: Curculionidae)
}

\author{
JUAN J. MORRONE \\ Laboratorio de Sistemática y Biología Evolutiva, Museo de La Plata, Paseo del Bosque, \\ 1900 La Plata, Argentina
}

\begin{abstract}
Ann. Entomol. Soc. Am. 87(4): 403-411 (1994)
ABSTRACT Acrostomus Kuschel is distinguished from other Rhytirrhinini Listroderina by its protruding epistome and the presence of a tooth in the scrobe. It includes (in cladistic sequence) A. cruralis Kuschel, A. griseus (Guérin), A. magellanicus Kuschel, A foveicollis Kuschel, A. bruchi (Hustache), A. vianai Kuschel, and A. mordor Morrone, $\mathrm{n}$. sp. Diagnostic characters, descriptions, and illustrations of the genus and species are given, a cladistic analysis is carried out, and a key for identifying the species is presented. This genus is endemic to the Patagonian biogeographic province of southern Argentina and Chile. Acrostomus cruralis is distributed on the Atlantic Coast, and the remaining species of the genus are found on the eastern margin of the Andean Cordillera.
\end{abstract}

KEY WORDS Rhytirrhinini, Patagonia, cladistics

The Patagonian STEPPES comprise the unforested areas east from the southern Andes to the Atlantic Coast and are characterized by xerophilous vegetation of spiny shrubs and hard grasses. Largely restricted to Argentina, they also extend in some places to Chile (Malleco, Aysén, and Magallanes), always to the east of the high Andean crest (Kuschel 1960, Peña 1966, O’Brien 1971). A basic feature of the weevil fauna of this area is the dominance of the Entimini; Cylydrorhinus Guérin has 50 species described from the area. Rhytirrhinini Listroderina, by contrast, are represented poorly. Recently, I revised $\mathrm{Hy}$ peroides Marshall (Morrone 1993a), which has one Patagonian species. In this article, I revise another genus of Listroderina, Acrostomus Kuschel, endemic to the area.

Acrostomus was established by Kuschel (1955 for Adioristus bruchi Hustache. Kuschel (1958) described A. cruralis, A. foveicollis, A. magellanicus, and A. vianai. Morrone (1994a), while analyzing the generic assignment of the species formerly placed in Listroderes Schoenherr, transferred L. griseus Guérin to Acrostomus. Examination of the collections of the Museo Argentino de Ciencias Naturales "Bernardino Rivadavia" (Buenos Aires, Argentina) led to the discovery of an undescribed species of this genus. This study provides a systematic and cladistic analysis of the species of Acrostomus.

\section{Materials and Methods}

Specimens were provided by the following institutions and private collections: American $\mathrm{Mu}$ - seum of Natural History (AMNH), New York (Lee H. Herman, Jr.); The Natural History Museum (BMNH), London (Christopher H. Lyal); Carlos Bordón, private collection (CBPC), Maracay, Venezuela; Charles W. O'Brien, private collection (CWOB), Tallahassee, FL; Fundación e Instituto Miguel Lillo (FIML), San Miguel de Tucumán, Argentina (Arturo L. Terán); Instituto Patagónico de Ciencias Naturales (IPCN), San Martín de los Andes, Argentina (Mario Gentili); Instituto de la Patagonia, Universidad de Magallanes (IPUM), Punta Arenas, Chile (José Petersen); Museo Argentino de Ciencias Naturales "Bernardino Rivadavia" (MACN), Buenos Aires, Argentina (Axel Bachmann); Museo Nacional de Historia Natural (MHNS), Santiago, Chile (Mario Elgueta); Museo de La Plata (MLP), La Plata, Argentina (Ricardo Ronderos); and National Museum of Natural History (USNM), Washington, DC (James Pakaluk).

Measurements were made with an ocular micrometer in a stereoscopic microscope. Body length was measured dorsally, along the midline, from the elytral apex to the fore margin of the prothorax. Drawings were made with the aid of a camera lucida attached to the stereoscopic microscope.

The species were analyzed cladistically using 34 morphological characters, with all multistate characters treated as nonadditive. The data matrix (Table 1) was analyzed applying the implicit enumeration option of Hennig86 version 1.5 (Farris 1988). The cladogram was rooted using the genus Listroderes Schoenherr. CLADOS 
version 1.1 (Nixon 1992) was employed for examination of enations.

reters analyzed are as follows:

1. Frons. [0] densely punctate; [1] sparsely punctate.

2. Rostral dorsum. [0] flat; [1] slightly convex; [2] strongly convex.

3. Rostral longitudinal carinae. [0] three; [1] two, lateral; [2] one, median.

4. Rostral basal impression. [0] absent; [1] present.

5. Scrobe. [0] lacking tooth; [1] with relatively small, weak protruding tooth; [2] with large, strong tooth.

6. Scape. [0] exceeding hind margin of eye when resting in scrobe; [1] reaching hind margin of eye when resting in scrobe.

7. Epistome. [0] not protruding; [1] protruding, with sharp posterior margin; [2] protruding, with smooth posterior margin.

8. Prothorax shape. [0] transverse or subcircular; [1] subquadrate.

9. Prothoracic base. [0] wider than apex; [1] as wide as apex.

10. Prothoracic longitudinal sulcus. [0] absent; [1] present, shallow; [2] present, deep.

11. Prothoracic lateral impressions. [0] absent; [1] present, superficial; [2] present, deep.

12. Prothoracic punctures. [0] sparse; [1] abundant.

13. Number of punctures on stria 4 . $[0]<25$; [1] $26-30$; [1] $>31$.

14. Interelytral suture. [0] not elevated at declivital area; [1] elevated at declivital area.

15. Declivital tubercles. [0] present; [1] absent.

16. Scutellum shape. [0] subtriangular; [1] elongate.

17. External margin of protibial apex. [0] lacking tooth; [1] with small tooth; [2] with large tooth.

18. Aedeagus. [0] robust in lateral view; [1] slender in lateral view.

19. Margins of aedeagus. [0] smooth; [1] rugose.

20. Internal sac. [0] lacking dentiform sclerites; [1] with dentiform sclerite.

21. Apodemes. [0] slightly longer than or as long as tube; [1] shorter than tube.

22. Female sternum 8 plate. [0] subcircular; [1] subpentagonal.

23. Length of arms of female sternum 8. [0] long, exceeding middle of plate; [1] short, not reaching middle of plate.

24. Base of arms of female sternum 8. [0] incised; [1] not incised.

25. Apical margin of female sternum 8. [0] with sparse setae; [1] with abundant setae.

26. Apodeme of female sternum 8. [0] expanded at apex; [1] not expanded at apex.
27. Hemisternites. [0] with setae; [1] lacking setae.

28. Styli. [0] digitiform; [1] strongly sclerotized, spoonlike; [2] strongly sclerotized, enlarged.

29. Spermatheca. [0] nodulus and ramus developed; [1] nodulus and ramus absent.

30. Integument. [0] smooth; [1] granulose.

31. Vestiture of prothorax and elytra. [0] subcircular scales; [1] setalike scales.

32. Setalike scales on rostrum. [0] absent; [1] covering longitudinal dorsal carina; [2] entirely covering dorsum.

33. Setalike scales on prothorax. [0] entirely covering pronotum; [1] in three stripes [2] in one median stripe [3] sparse.

34. Setalike scales on elytra. [0] sparse, not covering all; [1] abundant, covering all; [2] in small patches.

Results

\section{Acrostomus Kuschel}

Type species: Adioristus bruchi Hustache, 1926 (original designation)

Acrostomus Kuschel, 1955: 287, 1958: 232 (key); Wibmer \& O’Brien, 1986: 115 (list).

Diagnosis. Acrostomus is distinguished by the protruding epistome and the presence of a tooth on the ventral carina of the scrobe.

General habitus (Fig. 1). Medium to large (body length 7.3-13.8 mm). Integument black. Vestiture of setalike scales (subcircular in A. cruralis) and setae. Frons lacking fovea. Eyes ovate, medium, flat. Rostrum slightly curved, shorter than prothorax, with 1-3 longitudinal, dorsal carinae. Scrobes shallow, lateral, directed toward but not reaching eyes; ventral carina with tooth. Pterygia developed. Epistome protruding. Mandibles robust, external face with 2 setae. Antennae subapically inserted; scape generally reaching hind margin of eye when resting in scrobe; article 1 of funicle longer than 2 , articles $3-6$ subglobose; club elliptical. Prothorax usually subquadrate; postocular lobes present. Metepisternal suture present. Scutellum visible. Elytra ovate, wider than prothorax, convex; intervals usually flat (convex in A. foveicollis); humeri rounded; anteapical tubercles absent. Legs with robust femora; tibiae mucronate, with spurs; protibial apex externally with tooth; tarsomere 3 bilobate.

Male. Aedeagus (Figs. 2-15) sclerotized, slender or robust in lateral view; internal sac usually with dentiform sclerite; basal sclerites absent. Tegmen lacking parameres.

Female. Sternum 8 (Figs. 16-20) usually subcircular; with 2 sclerotized arms. Hemisternites (Figs. 21, 22) short; styli strongly sclerotized, api- 


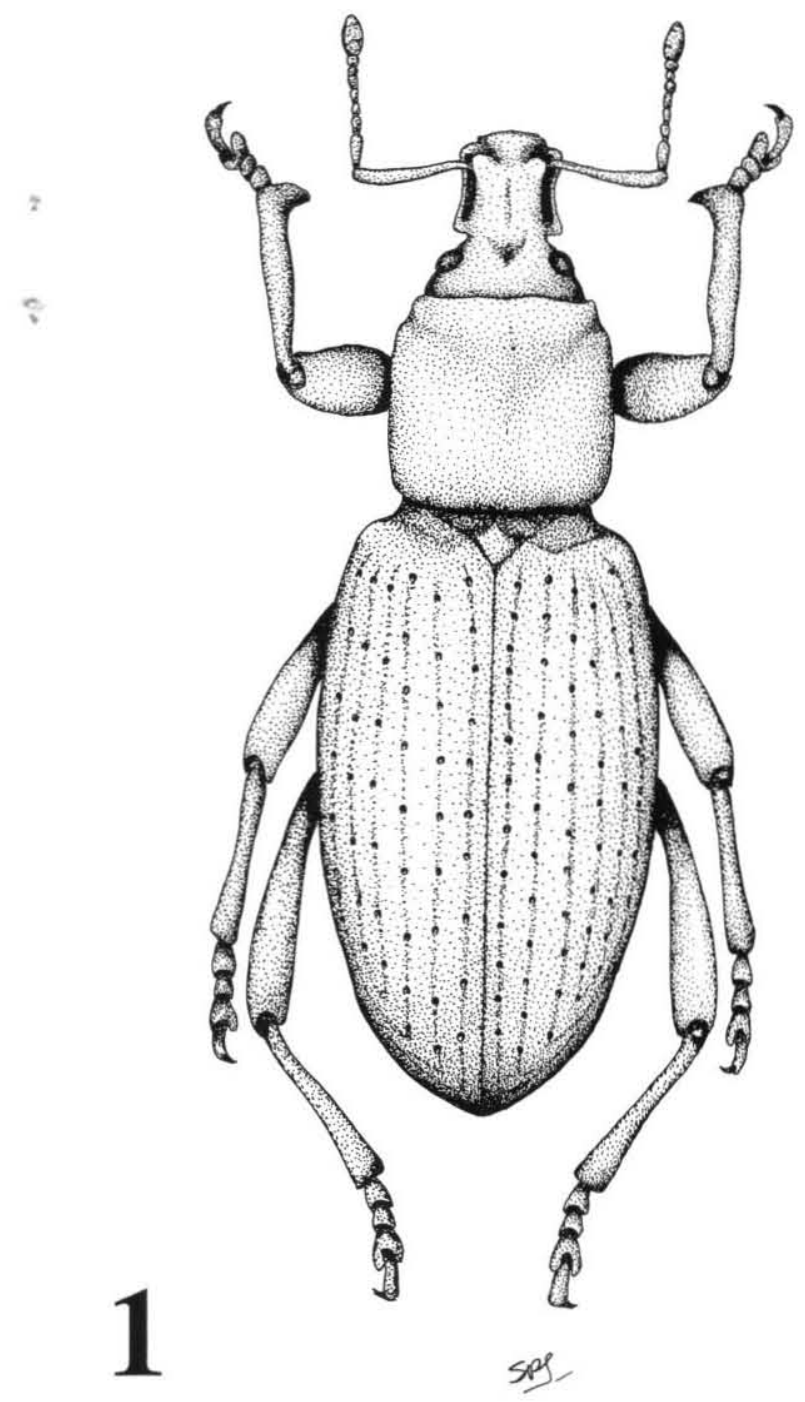

Fig. 1. Acrostomus bruchi, male habitus.

cal, generally spoonlike. Spermatheca (Figs. 23, 24) usually lacking nodulus and ramus.

Distribution and Habitat. Species of Acrostomus are endemic to the Patagonian biogeographic province (Cabrera \& Willink 1973). Acrostomus cruralis, from the Atlantic Coast, shows a remarkable disjunction in relation to the other species of the genus, which are found in the eastern margin of the Andean Cordillera (Fig. 25). Species of Acrostomus are associated with xerophilous plants of the genera Azorella, Bolax, and Mulinum (Apiaceae); larvae are green and live externally, feeding on the leaves of their host plants (Kuschel 1958).

Cladistics. Exact analysis of the matrix (Table 1) with Hennig86 resulted in one cladogram, stable to successive weighting, with 71 steps, a consistency index of 0.66 , and a retention index of 0.47 (Fig. 26). Species of Acrostomus are ar- ranged according to the following sequence: $A$. cruralis, A. griseus, A. magellanicus, A. foveicollis, A. bruchi, A. vianai, and A. mordor.

\section{Key to Species of Acrostomus}

1. Vestiture of subcircular scales; ventral carina of scrobe with 2 teeth; rostrum with 1 longitudinal dorsal carina; apex of protibia externally with prominent tooth .............cruralis Kuschel

Vestiture of setalike scales; ventral carina of scrobe with 1 tooth; rostrum with 2-3 longitudinal dorsal carinae; apex of protibia externally with slightly prominent tooth or lacking tooth . . . . . . 2

2 (1). Integument granulose; prothorax subcircular, covered with setalike scales; rostrum with flat dorsum, base lacking impression; each elytron with 3 declivital tubercles ....... griseus (Guérin) Integument smooth; prothorax subquadrate, setalike scales sparse, not covering all of surface or in $1-3$ stripes; rostrum with convex dorsum, base with deep impression; each elytron lacking declivital tubercles............. 3

3 (2). Setalike scales of prothorax in 3 stripes; apex of protibia externally lacking tooth .......... bruchi (Hustache) Setalike scales of prothorax sparse, not covering all surface, or in 2 stripes; apex of protibia externally with large tooth ................. . 4

4 (3). Rostrum with strongly convex dorsum, setalike scales covering longitudinal dorsal carina; epistome with smooth margin; prothorax with base wider than apex; each elytron with stria 4 with $<30$ punctures . . . . . . . . 5

Rostrum with slightly convex dorsum, lacking setalike scales; epistome with sharp margin; prothorax with base as wide as apex; each elytron with stria 4 with $>30$ punctures .........6 6

5 (4). Head with sparse punctation; scrobe with large, strong tooth; rostrum with 3 longitudinal dorsal carinae; prothorax with deep longitudinal sulcus; elytra with convex interstriae, stria 4 with $<25$ punctures; protibia with small mucro ......... foveicollis Kuschel Head with abundant punctation; scrobe with relatively small, weak tooth; rostrum with 2 longitudinal dorsal carinae; prothorax with slightly developed longitudinal sulcus; elytra with flat interstriae, stria 4 with $26-30$ punctures; protibia with large mucro ............ magellanicus Kuschel

6 (4). Head with abundant punctation; rostrum with 3 longitudinal dorsal cari- 
2

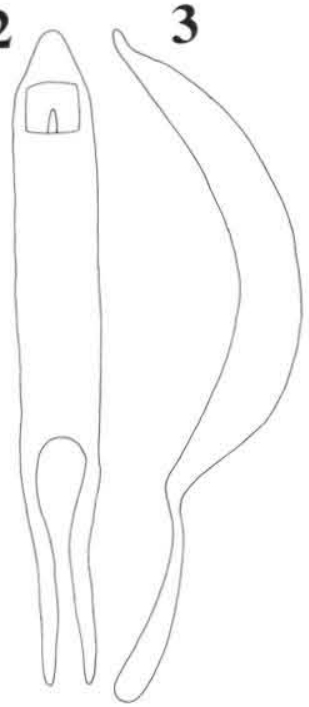

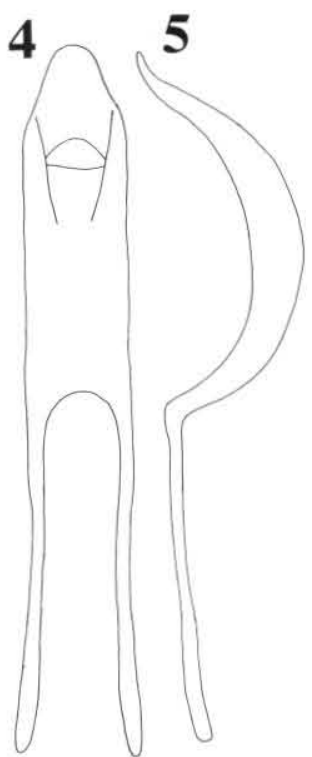
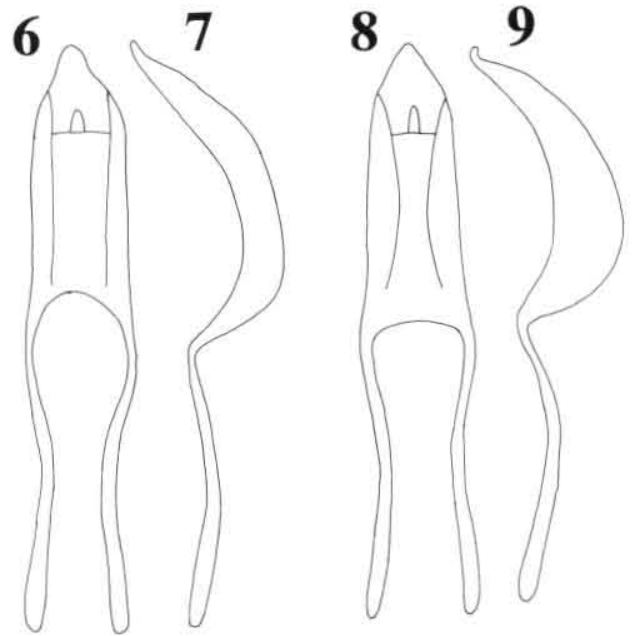

Figs. 2-9. Acrostomus, male genitalia. 2, 4, 6, 8, aedeagus, dorsal; 3, 5, 7, 9, aedeagus, lateral, 2, 3, A. griseus; 4,5, A. cruralis; 6,7, A. vianai; 8,9, A. mordor.

nae; prothorax lacking longitudinal sulcus, with sparse setalike scales in median portion

........................... Kuschel

Head with sparse punctation; rostrum with 2 longitudinal dorsal carinae; prothorax with slightly developed longitudinal sulcus, with sparse setalike scales in median portion

.......... mordor Morrone, n. sp.

\section{Acrostomus cruralis Kuschel}

(Figs. 4 and 5)

Acrostomus cruralis Kuschel, 1958: 234; Wibmer \& O’Brien, 1986: 115 (list).

Diagnosis. Distinguished by the following characters: rostrum with 1 longitudinal dorsal ca-
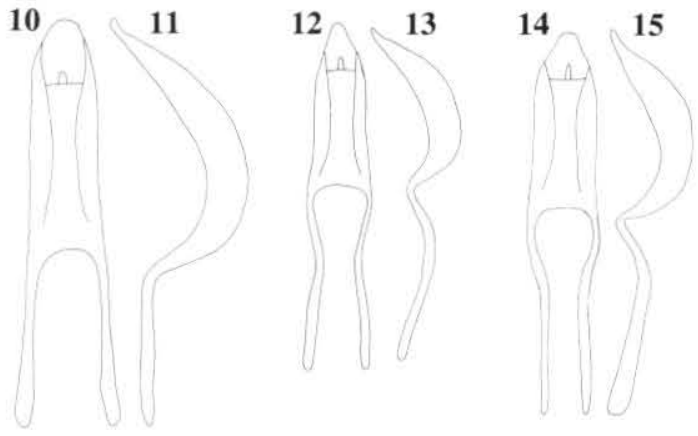

Figs. 10-15. Acrostomus, male genitalia. 10, 12, 14, aedeagus, dorsal; $11,13,15$, aedeagus, lateral; $10,11, A$. bruchi; 12, 13, A. magellanicus; 14, 15, A. foveicollis. rina, scrobes with 2 teeth, prothorax transverse, and body vestiture of subcircular scales.

Male. Integument granulose. Frons densely punctate. Rostrum with flat dorsum and 1 longitudinal dorsal carina; lacking transverse impression at base. Scrobes with 2 relatively small, weak teeth on ventral carina. Antennae with

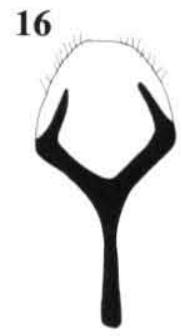

17

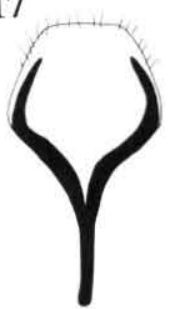

19

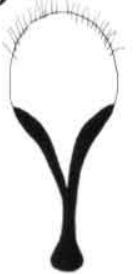

20
18
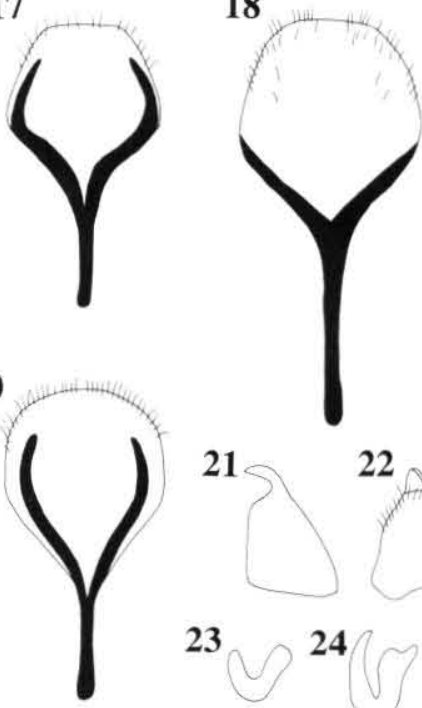

24
21

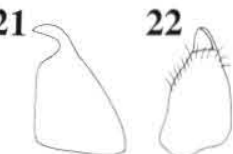

23
Figs. 16-24. Acrostomus, female genitalia, 16-20, female sternum 8 , ventral; 21,22 , hemisternite, ventral; 23, 24, spermatheca. 16, A. griseus; 17, 21, 23, A. mordor; 18, 24, A. bruchi $; 19$, A. magellanicus; 20, 22, A. foveicollis. 


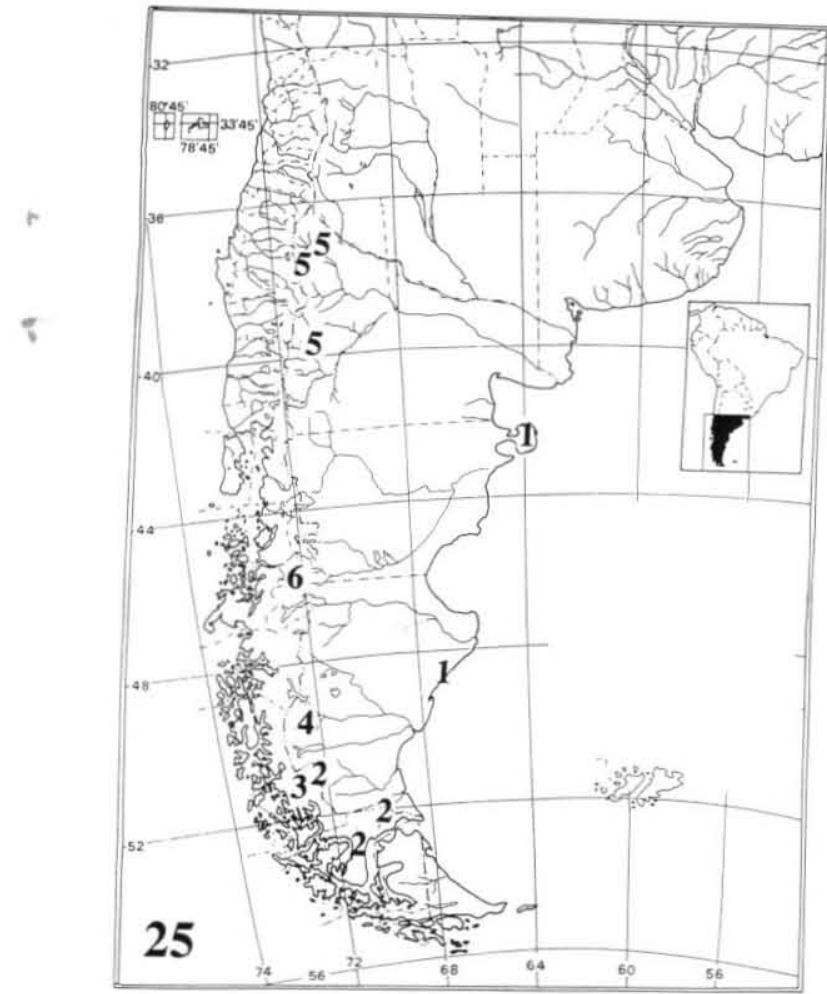

Fig. 25. Geographical distribution of the species of Acrostomus. 1, A. cruralis; 2 , A. griseus; 3 , A. magellanicus; 4, A. foveicollis; 5, A. bruchi; 6 , A. vianai.

scape reaching hind margin of eye when resting in scrobe. Epistome with sharp margin. Prothorax transverse, base wider than apex, sides strongly rounded; dorsum densely punctate, lacking longitudinal sulcus and lateral impressions; subcircular scales in 3 stripes. Scutellum elongate. Elytra with flat intervals; stria 4 with $>31$ punctures; interelytral suture elevated at declivital area; lacking declivital tubercle; sparsely covered with subcircular scales. Protibiae with large mucro; apex externally with large tooth. Aedeagus (Figs. 4, 5) slender in lateral view; margins smooth; internal sac lacking dentiform sclerite; apodemes as long as tube. Length $9.0-12.0 \mathrm{~mm}$.

Type Material. Holotype $q$ (11630), Argentina, Comodoro Rivadavia (MACN). Allotype $\delta$, Argentina, Chubut, Valdez Peninsula, XI-23, G. L. Harrington (USNM). Paratype, Argentina, Chubut (MACN).

\section{Acrostomus griseus (Guérin)}

(Figs. 2, 3, 16)

Listroderes griseus Guérin, 1839: 305; Blanchard, 1851: 337; Gemminger \& Harold, 1871: 2360 (cat.); Kolbe, 1907: 103 (cat.); Bruch, 1915: 414 (cat.); Schenkling \& Marshall, 1931:
Table 1. Data matrix for Acrostomus

\begin{tabular}{|c|c|}
\hline Taxon & $\begin{array}{ccc}1 & 2 & 3 \\
1234567890123456789012345678901234\end{array}$ \\
\hline Listroderes & 0000000000000000000000000000000000 \\
\hline A. cruralis & 002011100001111111000 ????????101?? \\
\hline A. griseus & 0000102000110000210111010101111201 \\
\hline A. magellanicus & 0111112101112010201100101001101020 \\
\hline A. foveicollis & 1101212102200111201100001101101020 \\
\hline A. bruchi & 0201111101211110201111111111001212 \\
\hline A. vianai & 020121111011111021110 ????????01130 \\
\hline A. mordor & 1211211111111110201101000112101120 \\
\hline
\end{tabular}

0 , Plesiomorphic character states; 1, 2, and 3, apomorphic characters states; ?, missing data.

8 (cat.); Blackwelder, 1947: 813 (list); Elgueta \& Jackson, 1987: 73 (list); Wibmer \& O'Brien, 1986: 114 (list)

Listroderes pubescens Germain, 1895: 481, 1911: 205 (list); Kolbe, 1907: 104 (cat.); Bruch, 1915: 415 (cat.); Kuschel, 1955: 289 (= L. griseus); Elgueta \& Morrone, 1993: 138 (types).

Acrostomus griseus: Morrone, 1994a: 6.

Diagnosis. Distinguished by the following characters: subcircular prothorax, each elytron with 3 declivital tubercles, and entirely covered by setalike scales.

Male. Integument granulose. Frons densely punctate. Rostrum with flat dorsum and 3 longitudinal dorsal carinae; lacking transverse impression at base; entirely covered by setalike scales. Scrobes with relatively small, weak tooth on ventral carina. Antennae with scape exceeding hind margin of eye when resting in scrobe. Epistome with smooth margin. Prothorax subcircular, base wider than apex, sides strongly rounded; dorsum densely punctate, lacking longitudinal sulcus, with 2 superficial, subcircular, lateral impressions; entirely covered by setalike scales. Scutellum subtriangular. Elytra with flat intervals; stria 4 with $<25$ punctures; interelytral suture not elevated at declivital area; with 3 slightly developed declivital tubercles in intervals 2-4; setalike scales abundant, covering elytral surface. Protibiae with large mucro; apex externally with small tooth. Aedeagus (Figs. 2, 3) slender in lateral view; margins smooth; internal sac with dentiform sclerite; apodemes shorter than tube.

Female. Sternum 8 (Fig. 16) subpentagonal, apical margin with sparse setae; arms long, exceeding middle of plate, basally not incised; apodeme not expanded at apex. Hemisternites similar to those of A. foveicollis (Fig. 22), with setae; styli spoonlike. Spermatheca similar to that of $A$. mordor (Fig. 23), nodulus and ramus absent.

Length 7.7-10.1 mm.

Type Material. Lectotype of L. pubescens, Chile, Magallanes (MHNS). Seven paralectotypes with the same data (MHNS). 


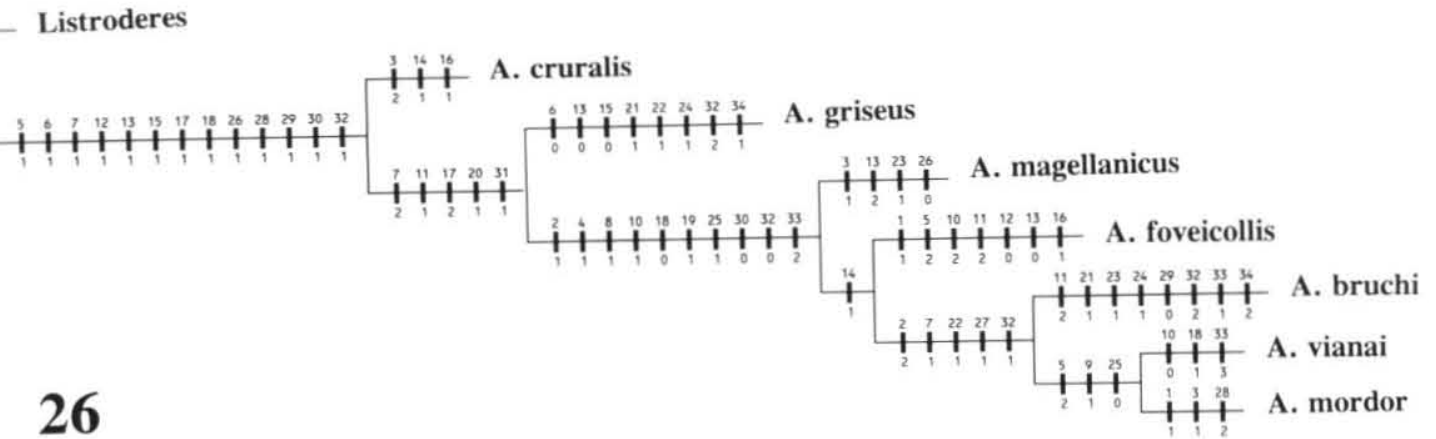

Fig. 26. Cladogram of the species of Acrostomus.

Other Material Examined. ARGENTINA (without precise data): "Patagonia," 2 (MLP). CHILE: Magallanes: Dos Lagunas, "under wood," 14-I-68, C. W. \& L. O'Brien coll., 3 (CWOB); Estancia Brazo Norte, 24-X-80, J. Petersen coll., 1 (IPUM); Río Pescado, 16-I-68. L. \& C. W. O'Brien coll., 1 (CWOB); Río Verde (beach), "under wood," 16-I-68, C. W. \& L. O'Brien coll., 48 (CWOB); Seno Otway, Laguna del Toro, 19-XI-50, T. Cekalovic coll., 2 (FIML); Ush Aike, 6-III-78, M. Martinic coll., 1 (IPUM).

\section{Acrostomus magellanicus Kuschel}

(Figs. 12, 13, 19)

Acrostomus magellanicus Kuschel, 1958: 233; Cekalovic, 1974: 307 (biogeog.); Wibmer \& O'Brien, 1986: 115 (list).

Diagnosis. Distinguished by the expanded apex of the apodeme of female sternum 8.

Male. Integument smooth. Frons densely punctate. Rostrum with flat dorsum and 1 longitudinal dorsal carina; with transverse impression at base; setalike scales restricted to median carina. Scrobes with relatively small, weak tooth on ventral carina. Antennae with scape reaching hind margin of eye when resting in scrobe. Epistome with smooth margin. Prothorax subquadrate, base wider than apex, sides subparallel; dorsum densely punctate, with shallow longitudinal sulcus and 2 superficial, subcircular, lateral impressions; setalike scales in median stripe. Scutellum subtriangular. Elytra with flat intervals; stria 4 with $26-30$ punctures; interelytral suture not elevated at declivital area; lacking declivital tubercle; setalike scales sparse. Protibiae with large mucro; apex externally with small tooth. Aedeagus (Figs. 12, 13) robust in lateral view; margins rugose; internal sac with dentiform sclerite; apodemes slightly longer than tube.

Female. Sternum 8 (Fig. 19) subcircular, apical margin with abundant setae; arms short, not reaching middle of plate, basally incised; apodeme expanded at apex. Hemisternites similar to those of A. foveicollis (Fig. 22), with setae; styli spoonlike. Spermatheca similar to that of A. mordor (Fig. 23), nodulus and ramus absent.

Length $8.5-9.4 \mathrm{~mm}$.

Type Material. Two paratypes, Chile, Magallanes, $\mathrm{C}^{\circ}$ Castillo, $\mathrm{C}^{\circ}$ Cazador, $800 \mathrm{~m}, 9-\mathrm{II}-57$, s/ Azorella sp., Kuschel (1 BMNH, 1 USNM).

Other Material Examined. CHILE: Magallanes: Cerro Castillo, 10-II-57, T. Cekalovic coll., 1 (MHNS); Cerro Guido, 11-II-57, T. Cekalovic coll., 1 (USNM).

\section{Acrostomus foveicollis Kuschel}

(Figs. 14, 15, 20, 22)

Acrostomus foveicollis Kuschel, 1958: 232; Wibmer \& O’Brien, 1986: 115 (list).

Diagnosis. Distinguished by the deep longitudinal sulcus in the prothorax and the small protibial mucro.

Male. Integument smooth. Frons sparsely punctate. Rostrum with strongly convex dorsum and 3 longitudinal dorsal carinae; with transverse impression at base; setalike scales restricted to median carina. Scrobes with large, strong tooth on ventral carina. Antennae with scape reaching hind margin of eye when resting in scrobe. Epistome with smooth margin. Prothorax subquadrate, base wider than apex, sides subparallel; dorsum sparsely punctate, with deep longitudinal sulcus and 2 deep, subcircular, lateral impressions; setalike scales in median stripe. Scutellum elongate. Elytra with convex intervals; stria 4 with $<25$ punctures; interelytral suture elevated at declivital area; lacking declivital tubercle; setalike scales sparse. Protibiae with small mucro; apex externally with small tooth. Aedeagus (Figs. 14, 15) robust in lateral view; margins rugose; internal sac with dentiform sclerite; apodemes slightly longer than tube.

Female. Sternum 8 (Fig. 20) subcircular, apical margin with abundant setae; arms long, exceeding middle of plate, basally incised; apodeme not expanded at apex. Hemisternites (Fig. 22) with 
setae; styli spoonlike. Spermatheca similar to that of A. mordor (Fig. 23), nodulus and ramus absent.

Length $9.8-10.7 \mathrm{~mm}$.

Material Examined. ARGENTINA: Santa Cruz: Lago Viedma, 1/3-III-74, Bordón coll., 5 (2 CBPC, 1 CWOB, 2 MHNS).

\section{Acrostomus bruchi (Hustache)}

(Figs. 1, 10, 11, 18, 24)

Adioristus bruchi Hustache, 1926: 186; Schenkling \& Marshall, 1931: 4 (cat.); Blackwelder, 1947: 812 (list); Ringuelet, 1955: 101 (biogeog.).

Acrostomus bruchi: Kuschel, 1955: 289; Wibmer \& O’Brien, 1986: 115 (list).

Diagnosis. Distinguished by the small patches of setalike scales on the elytra.

Male (habitus, Fig. 1). Integument smooth. Frons densely punctate. Rostrum with slightly convex dorsum and 3 longitudinal dorsal carinae; with transverse impression at base; entirely covered by setalike scales. Scrobes with relatively small, weak tooth on ventral carina. Antennae with scape reaching hind margin of eye when resting in scrobe. Epistome with sharp margin. Prothorax subquadrate, base wider than apex, sides subparallel; dorsum densely punctate, with shallow longitudinal sulcus and 2 deep, subcircular, lateral impressions; setalike scales in 3 stripes. Scutellum subtriangular. Elytra with flat intervals; stria 4 with $>31$ punctures; interelytral suture elevated at declivital area; lacking declivital tubercle; setalike scales in small patches. Protibiae with large mucro; apex externally with small tooth. Aedeagus (Figs. 10, 11) robust in lateral view; margins rugose; internal sac with dentiform sclerite; apodemes shorter than tube.

Female. Sternum 8 (Fig. 18) subpentagonal, apical margin with abundant setae; arms short, not reaching middle of plate, basally not incised; apodeme not expanded at apex. Hemisternites similar to those of A. foveicollis (Fig. 22), lacking setae; styli spoonlike. Spermatheca (Fig. 24), nodulus and ramus slightly developed.

Length 8.5-13.8 mm.

Material Examined. ARGENTINA: Neuquén: Chacayal, 26-XII-57, S. Schajovskoy coll., 1 (MLP); Collón Cura, 8-XII-55, S. Schajovskoy coll., 7 (MLP); Rìo Aluminé, 8-XI-55, C. Giai coll., 1 (MLP); Sañico, $1000 \mathrm{~m}, 23-\mathrm{XI}-68,1$ (IPCN); without precise data, 1 (MLP). Río Negro: Bariloche, Richter coll., 6 (MLP); without precise data, 20 (1 CWOB, $19 \mathrm{MACN})$. Without precise data: 3 (2 CWOB, 1 MLP).

\section{Acrostomus vianai Kuschel}

(Figs. 6 and 7)

Acrostomus vianai Kuschel, 1958: 233; Wibmer \& O’Brien, 1986: 115 (list).
Diagnosis. Distinguished by the prothorax with sparse setalike scales in median portion.

Male. Integument smooth. Frons densely punctate. Rostrum with slightly convex dorsum and 3 longitudinal dorsal carinae; with transverse impression at base; lacking setalike scales. Scrobes with large, strong tooth on ventral carina. Antennae with scape reaching hind margin of eye when resting in scrobe. Epistome with sharp margin. Prothorax subquadrate, base as wide as apex, sides subparallel; dorsum densely punctate, lacking longitudinal sulcus, with 2 superficial, subcircular, lateral impressions; setalike scales sparse, in median portion. Scutellum subtriangular. Elytra with flat intervals; stria 4 with $>31$ punctures; interelytral suture elevated at declivital area; lacking declivital tubercle; setalike scales sparse. Protibiae with large mucro; apex externally with small tooth. Aedeagus (Figs. 6, 7) slender in lateral view; margins rugose; internal sac with dentiform sclerite; apodemes as long as tube. Length $8.6-11.0 \mathrm{~mm}$.

Type Material. Paratype, Argentina, Neuquén, Kuschel (USNM). Paratype, Chile, Aysén, Balmaceda, 20-II-57, s/ Azorella trifurcata (BMNH).

Other Material Examined. ARGENTINA: Chubut: "Patagonia," 2 (BMNH). CHILE: Aysén: Balmaceda, 29-I-77, Silva coll., 1 (MHNS).

\section{Acrostomus mordor Morrone, n. sp.}

(Figs. 8, 9, 17, 21, 23)

Diagnosis. Distinguished by the enlarged styli of the hemisternites.

Holotype male. Integument smooth. Frons sparsely punctate. Rostrum with slightly convex dorsum and 1 longitudinal dorsal carina; with transverse impression at base; lacking setalike scales. Scrobes with large, strong tooth on ventral carina. Antennae with scape reaching hind margin of eye when resting in scrobe. Epistome with sharp margin. Prothorax subquadrate, base as wide as apex, sides subparallel; dorsum densely punctate, with shallow longitudinal sulcus and 2 superficial, subcircular, lateral impressions; setalike scales in median stripe. Scutellum subtriangular. Elytra with flat intervals; stria 4 with $>31$ punctures; interelytral suture elevated at declivital area; lacking declivital tubercle; setalike scales sparse. Protibiae with large mucro; apex externally with small tooth. Aedeagus (Figs. 8, 9) robust in lateral view; margins rugose; internal sac with dentiform sclerite; apodemes slightly longer than tube. Length $7.3 \mathrm{~mm}$.

Female. Sternum 8 (Fig. 17) subpentagonal, apical margin with sparse setae; arms long, not reaching middle of plate, basally incised; apodeme not expanded at apex. Hemisternites (Fig. 21) lacking setae; styli enlarged. Spermatheca (Fig. 23), nodulus and ramus absent. 
Type Material. Holotype (10264), Argentina, Neuquén (MACN). Nine paratypes with the same data (2 AMNH, 5 MACN, 2 MLP).

Etymology. The name of this species is taken from the Land of Mordor, in Tolkien's The Lord of the Rings.

\section{Discussion}

The cladistic analysis confirms the assignment of A. griseus to the genus (Morrone 1994a). All clades of Acrostomus are well supported, and all species have particular combinations of apomorphic and homoplastic characters. It is interesting to note that parallellisms affecting characters from genitalia (21-24) are only those provided by female sternum 8 , whereas the other characters from genitalia (e. g., those provided by aedeagus [18-20], hemisternites [27, 28], or spermatheca [29]) are synapomorphies or only show reversals.

The Rhytirrhinini Listroderina are mainly Andean (Morrone 1990, 1992a, b, c, 1993b, 1994a, c); only Acrostomus is endemic to the Patagonian steppes. Its distribution can be compared with that of Hyperoides Marshall (Morrone 1993a), which has one species in the latter area. In Hyperoides, the three more basal species are from central Chile, and the two most apomorphic species are found, respectively, in coastal Patagonia and in the Chacoan biogeographic domain. In Acrostomus, the coastal Patagonian species is the most basal one, and the remaining species are found in the cordillera.

Patterns of these genera, as well as those of other taxa of the area, reflect the existence of an ancient subtropical biota in Patagonia (Ringuelet 1961, Pascual \& Ortiz Jaureguizar 1990, Morrone 1994b, Morrone \& Lopretto 1994). Fossil evidence indicates that a humid subtropical forest covered southern South America before the Eocene and that the gradual uplift of the Andes, from the late Oligocene to the Pliocene, cut off the Pacific wind drift and induced aridity in vast areas. In the middle Miocene, extensive opencountry environments ranging from wetter subtropical savannas to cold-temperate steppes developed in the area (Pascual \& Ortiz Jaureguizar 1990). It seems that the species of Acrostomus evolved simultaneously with the development of these environments.

\section{Acknowledgments}

I am grateful to Lee H. Herman Jr., Charlie O'Brien, and an anonymous reviewer for critically reading the manuscript. This study was supported by National Geographic Society grant 4662-91 and a National Science Foundation research fellowship at the Department of Entomology of the American Museum of Natural History (New York). Support of the Consejo Nacional de Investigaciones Científicas y Técnicas
(CONICET), Argentina, to which the author belongs, is gratefully acknowledged.

\section{References Cited}

Blackwelder, R. E. 1947. Checklist of the Coleopterous insects of Mexico, Central America, the West Indies, and South America. Part 5. U.S. Natl. Mus. Bull. 185: 765-925.

Blanchard, C. E. 1851. Fauna Chilena, Insectos. Coleópteros, pp. 286-429 In Gay, C. Historia física y política de Chile, Zoología, vol. 5, Paris.

Bruch, C. 1915. Catálogo sistemático de los coleópteros de la República Argentina. Rev. Mus. La Plata, 1914 [1915] 19: 401-441.

Cabrera, A. L. \& A. Willink. 1973. Biogeografía de América Latina. Monografía 13, Serie de Biología, Organización de Estados Americanos, Washington DC.

Cekalovic, T. 1974. Divisiones biogeográficas de la XII región chilena (Magallanes). Bol. Soc. Biol. Concepcion 48: 297-314.

Elgueta, M. \& D. Jackson. 1987. Nombre actual de las especies de Curculionoidea (Insecta: Coleoptera) tratadas en la obra de Gay. Rev. Chil. Entomol. 15: $71-78$.

Elgueta, M. \& J. J. Morrone. 1993. Los ejemplares tipo de "Listroderitos" (Coleoptera: Curculionidae) de Germain (1895-1896), de la colección del Museo Nacional de Historia Natural (Santiago, Chile). Bol. Mus. Nac. Hist. Natl., Chile, 1992 [1993] 43: 131142.

Farris, J. S. 1988. Hennig86 reference, version 1.5. Published by the author, Port Jefferson.

Gemminger, M. \& E. von Harold [eds.]. 1871. Catalogus Coleopterorum hucusque descriptorum synonymicus et systematicus, pp. 2181-2668. Gummi, Monachii, vol. 8. Curculionidae.

Germain, P. 1895-96. Apuntes sobre los insectos de Chile. Estudio y descripción de los Listroderitos de Chile y tierras magallánicas de la colección del Museo Nacional i la de Don Fernando Paulsen. An. Univ. Chile 90: 287-324, 467-505, 567-602, 91: 53-104 (1895); 93: 791-838, 94: 721-752 (1896).

1911. Informes de los jefes de Sección i otros empleados del Museo. 1-Informe del jefe de la Sección de Entomolojía. Bol. Mus. Nac. Chile 3: 197-221.

Guérin, F. E. 1839. Description de quelques Coléoptè res des côtes du Detroit de Magellan. Rev. Zool. 2: 295-305.

Hustache, A. 1926. Contribution à l'étude des Curculionides de la République Argentine (premiére note). An. Mus. Nac. Hist. Natl. Bernardino Rivadavia 34: 155-261.

Kolbe, H. J. 1907. Coleopteren. Ergebnisse der Hamburger Magalhaensische Sammelreise 8(4): $1-125$.

Kuschel, G. 1955. Nuevas sinonimias y anotaciones sobre Curculionoidea (1) (Coleoptera). Rev. Chil. Entomol. 4: 261-312.

1958. Nuevos Cylydrorhininae de la Patagonia (Col. Curculionoidea, Aporte 18). Invest. Zool. Chil. 4: 231-252.

1960. Terrestrial zoology in southern Chile. Proc. R. Soc. Lond. Biol. Sci. 152: 540-550.

Morrone, J. J. 1990. Philippius Germain, a remarkable Listroderini from southern South America 
(Coleoptera: Curculionidae). Coleopt. Bull. 44: 429-436.

1992a. Revisión sistemática y análisis cladístico del género Antarctobius Fairmaire (Coleoptera: Curculionidae). Neotropica (La Plata) 38: 3-20.

1992b. Revisión sistemática, análisis cladístico y biogeografía histórica de los géneros Falklandius Enderlein y Lanteriella gen. nov. (Coleoptera: Curculionidae). Acta Entomol. Chil. 17: 157-174.

1992c. Revision of Trachodema Blanchard with the description of an allied genus from central Chile (Insecta, Coleoptera, Curculionidae). Zool. Scr. 21: 417-422.

1993a. Revisión sistemática del género Hyperoides Marshall (Coleoptera: Curculionidae). Neotropica (La Plata) 39: 17-26.

1993b. Revisión sistemática de un nuevo género de Rhytirrhinini (Coleoptera: Curculionidae), con un análisis biogeográfico del dominio subantártico. Bol. Soc. Biol. Concepcion. 64: 121-145

1994a. Clarification of the taxonomic status of the species formerly placed in Listroderes Schoenherr (Coleoptera: Curculionidae), with the description of a new genus. Am. Mus. Novit. 3086.

1994b. Cladistic and biogeographic analyses of the weevil genus Listroderes Schoenherr (Coleoptera: Curculionidae). Cladistics (in press).

1994c. Systematics of the Andean genus Acrorius Kirsch (Coleoptera: Curculionidae). Coleopt. Bull. 48 (in press).

Morrone, J. J. \& E. C. Lopretto. 1994. Distributional patterns of freshwater Decapoda (Crustacea:
Malacostraca) in southern South America: A panbiogeographic approach. J. Biogeogr. 21 (in press).

Nixon, K. C. 1992. CLADOS ver. 1.1. IBM PC compatible character analysis program. Published by the author, Cornell University, Ithaca, NY.

O'Brien, C. W. 1971. 1971. The biogeography of Chile through entomofaunal regions. Entomol. News 82: 197-207.

Pascual, R. \& E. Ortiz Jaureguizar. 1990. Evolving climates and mammal faunas in Cenozoic South America. J. Hum. Evol. 19: 23-60.

Peña, L. E. 1966. A preliminary attempt to divide Chile into entomofaunal regions, based on the Tenebrionidae (Coleoptera). Postilla 97: 17.

Ringuelet, R. A. 1955. Vinculaciones faunísticas de la región boscosa del Nahuel Huapi y el dominio zoogeográfico Australcordillerano. Notas Mus, La Plata 18: 81-121.

1961. Rasgos fundamentales de la zoogeografía de la Argentina. Physis (B. Aires) 22: 151-170.

Schenkling, S. \& G. A. K. Marshall. 1931. Curculionidae, Cylindrorhininae. In Junk Coleopterorum Catalogus, Berlin, 27: 1-23.

Wibmer, G. J. \& C. W. O'Brien. 1986. Annotated checklist of the weevils (Curculionidae sensu lato) of South America (Coleoptera: Curculionoidea). Mem. Am. Entomol. Inst. (Gainesville) 39: i-xvi, $1-563$.

Received for publication 9 September 1993; accepted 23 November 1993. 